\title{
The Idea of Corporate Social Responsibility in the Opinion of Future Managers-Comparative Research between Poland and Georgia
}

\author{
Iwona Zdonek ${ }^{1}$ (D), Anna Mularczyk ${ }^{1, *(1)}$ and Grzegorz Polok ${ }^{2}$ (D) \\ 1 Department of Organization and Management, Institute of Economy and Informatics, \\ Silesian University of Technology, 44-100 Gliwice, Poland; iwona.zdonek@polsl.pl \\ 2 Department of Public Management and Social Sciences, University of Economics in Katowice, \\ 40-287 Katowice, Poland; grzegorz.polok@uekat.pl or grzegorz.polok@ue.katowice.pl \\ * Correspondence: anna.mularczyk@polsl.pl
}

check for updates

Citation: Zdonek, I.; Mularczyk, A.; Polok, G. The Idea of Corporate Social Responsibility in the Opinion of Future Managers-Comparative Research between Poland and Georgia. Sustainability 2021, 13, 7045. https://doi.org/10.3390/su13137045

Academic Editor: Wen-Hsien Tsai

Received: 13 May 2021

Accepted: 18 June 2021

Published: 23 June 2021

Publisher's Note: MDPI stays neutral with regard to jurisdictional claims in published maps and institutional affiliations.

Copyright: (c) 2021 by the authors. Licensee MDPI, Basel, Switzerland. This article is an open access article distributed under the terms and conditions of the Creative Commons Attribution (CC BY) license (https:/ / creativecommons.org/licenses/by/ $4.0 /)$.

\begin{abstract}
The article deals with the issue of corporate social responsibility (CSR) in the awareness of economics students as future managers responsible for the implementation of this idea in enterprises. Due to the fact that CSR is a source of many innovations today, the aim of the research was to learn about the awareness and opinions of students about CSR on such issues as: reasons for implementation, main activities, impact on profitability, and the need to explore and assess the usefulness of this knowledge. The research was conducted in 2019 among students from Poland and Georgia (as countries at various stages of advancement in the market economy). The results of the research were statistically analyzed in terms of obtaining answers to the hypotheses and research questions, checking the significance of differences in the answers due to nationality, and additionally, gender (chi-square test and test for two proportions). The primary contribution of this study is an exploration of the views of students on various issues of CSR and sustainability. The results showed that-according to students-ethical values, increased consumer awareness, and the desire to gain a competitive advantage are the most common reasons for the implementation of the CSR concept by companies. The vast majority of respondents indicated the need to enrich the knowledge of business ethics as an important aspect shaping the attitudes of employers and employees. The positive attitude of students regarding the impact of CSR on the company's profitability was confirmed, although the authors expected more unambiguous results. Differences were also distinguished between the responses of students from both countries on some issues, such as: opinions on the developing ethical sensitivity, the need for the credibility of the EU economic policy, ecology and relations with the local community, as well as relations with the closest stakeholders of companies. The results of the conducted research suggest the need for intense activity in the field of public awareness and the requirement of personnel training for the skilful implementation of CSR principles in enterprises.
\end{abstract}

Keywords: corporate social responsibility; the attitude of future managers towards CSR; ethical aspects of companies' operations

\section{Introduction}

Innovation in business is part of a self-perpetuating virtuous circle. It leads to higher productivity and efficiency, which, in turn, drives innovation [1]. Although the sources of innovation are undoubtedly new technologies [2] and new social behaviors [3,4], many contemporary researchers argue that corporate social responsibility (CSR) becomes the flywheel of many innovations. CSR covers the methods by which an enterprise can obtain added value by dealing with the social and environmental aspects of its operations. Thus, it is a concept whereby enterprises voluntarily incorporate social and environmental interests in their market action strategies, as well as in their relationships with various stakeholder groups [5]. Conducting social dialogue at the local level is not only conducive 
to increasing the competitiveness of enterprises at the global level but also-importantlyshaping the conditions for sustainable social and economic development [6]. According to the research [7], CSR as an innovation process is driven, on the one hand, by social and ecological values and, on the other hand, by economic value. Companies that want to develop and meet the expectations of stakeholders turn to the concept of CSR. They use social innovation to improve their supply chains and reach out to socially and environmentally conscious consumers and often work with social innovators to deliver business solutions to social needs [8]. According to the research [9], social innovation is seen as a key driver of the transition from ad hoc philanthropic programmes to genuine sustainable development strategies.

Since, in the future, economics students will especially create management personnel of various organizations, hence the state of their knowledge, as well as acceptance and willingness to use the principles of corporate social responsibility, are very important, as this will determine the actual transmission of this idea into the social and economic reality. That is why, at universities educating in the fields of economics and management, it is particularly important to explore issues related to corporate social responsibility. Realizing the importance of the problem, an attempt was made to diagnose the actual state of awareness of these students [6]. Until now, most of the research in this area has covered developed or developing countries. Comparative studies between the countries that are between this continuum are in the minority and usually involve closely neighboring countries $[10,11]$. Therefore, with this state in mind, we diagnosed a research gap that needs to be filled.

Analyzing the approach in the countries of the former Eastern bloc, Poland, as a rapidly developing country, and Georgia, as a country moving slower towards a market economy, were selected as representatives. This is confirmed by the ranking presented in the [12], created on the basis of GDP per capita, adjusted for purchasing power parity (PPP). Poland ranks 46th and Georgia 105th. This allows the assumption that both countries are at a different stage of building civic awareness [13,14], which is confirmed by the ranking [15], also the Global Innovation Index 2020 report [1], and this creates the main premise for the research undertaken in this article.

Bearing in mind the diagnosed research gap, the aim of this article has been divided into four parts. All of them concern the examination of the awareness and opinions of students on the following issues: (1) reasons for the implementation of the CSR idea by companies, (2) main measures characterizing the activities of companies in the field of CSR; (3) the impact of CSR on the profitability of companies; (4) the needs in the field of exploring and assessing the usefulness of knowledge on the ethical aspects of business operations.

To implement the first and second parts, we asked the following research questions:

Research Question 1: What is the awareness of economics students in terms of contemporary reasons for implementing the CSR idea by companies? Do nationality and gender influence attitudes in this regard?

Research Question 2: What, in the opinion of economics students, characterizes the activities of companies in the field of CSR? Are there any differences based on nationality or gender?

We were inspired to pose these questions by looking at the implementation of CSR in various countries from a historical perspective [16-19], showing that the origins of this concept were associated with charity activities of companies, and then with pro-employee and pro-ecological attitudes. Literature studies on the maturity of the implementation of CSR concepts in companies show that the implementation of this concept may have an incidental, tactical or strategic level [20] and largely depends on the state of the general economy and even specific industries. However, the activities of companies related to the concept of CSR always widely echo in the mass media, causing changes in the awareness of society (including consumers) regarding the importance of the CSR idea. Therefore, an 
interesting question is how this awareness is shaped in Poland and Georgia among young people who associate their professional future with the business.

To implement the third and fourth parts, we asked the following research questions:

Research Question 3: How, in the opinion of young people, does the implementation of CSR principles affects the profitability of companies? Do nationality and gender influence this opinion?

Research Question 4: What attitudes are represented by young people in terms of the exploration and usefulness of knowledge about the ethical aspects of business? Do these attitudes differ according to nationality and gender?

We were inspired to pose such questions from the literature research, which shows that the idea of CSR is perceived as generating revenues, that not only cover the costs of its implementation but also allow to achieve a competitive advantage [21-27]. On the other hand, there are also studies in which the idea of CSR is perceived as a space for manipulation under the guise of altruistic concern, which makes the idea of CSR having a negative impact on financial results [28]. Therefore, it is puzzling which of these concepts is more convincing to the public.

The research questions posed by us indicate that the nature of our research is exploratory. In our research, we focus on learning about the views of students (from two countries that differ in terms of the development of the market economy) on various issues of CSR and sustainable development. The implementation of the set goals and answers to the research questions determined the organization of this article. The paper is organized as follows. Section 2 highlights hypotheses development in terms of: (1) reasons for implementing the CSR idea, (2) characteristic activities of companies implementing CSR, (3) attitudes regarding the impact of CSR on the profitability of companies, (4) attitudes towards the usefulness of knowledge in the field of CSR. Section 3 describes the methodology of the empirical research. Results are reported in Section 4. Discussion of findings and theoretical and practical implications are described in Section 5. Section 6 presents limitations and Section 7 conclusion.

\section{Literature Review and Hypotheses Development}

\subsection{Reasons for Implementing the CSR Idea}

An interesting look at the reasons for implementing the CSR concept in companies is the historical approach to the development of this concept, proposed in the paper [16]. Already in ancient Rome, charity work was visible in the form of creating asylum, houses for the poor and the old, hospitals and orphanages. In the Middle Ages, the activities of the Romans continued in municipal and religious institutions [17]. Some corporations joined charity work in the 16th and 17th centuries. In the 18th and 19th centuries, during the domination of the British Empire, the concept of Victorian philanthropy appeared. It focused on the working class and the creation of social programmes, examples of which could be seen in practice, both in Europe and in the United States of America [18,19]. The end of the 19th century and the beginning of the 20th century saw the popularization of donations to orphan shelters and the creation of model industrial communities, in order to improve the quality of life of employees in the form of building workers' housing estates [18]. In the 1920s and 1930s, business managers began to take responsibility for balancing profit maximization with creating and maintaining a balance with the demands of customers, workforce and the community [18]. Together with the development of the business during World War II and the 1940s, companies began to be perceived as socially responsible institutions, and these responsibilities were discussed more extensively. In the 1950s and 1960s, the belief arose that companies were responsible not only for their legal and economic obligations, but should be concerned with the welfare of the community and the education and happiness of their employees [16]. Moreover, in the 1970s, after numerous environmental disasters, such as the oil spill, the public was concerned about the rapid population growth, resource depletion and environmental pollution [29]. This 
resulted in numerous social movements in the field of environmental protection, as well as human and labor rights. These movements continued in the 1980s, where, in addition to environmental issues, there were also protests against employment discrimination and consumer abuse. Moreover, there were protests against such activities of companies that threatened the health and safety of employees and worsened the quality of life in the city. The aggressive practices of international corporations were also publicized and criticized. Movements and social unrest led to the creation of social and environmental laws that imposed additional obligations on companies regarding environmental protection, product safety and labor rights [18].

It is not only the historical analysis of the CSR concept that gives an insight into the reasons why companies implement this idea. Interesting conclusions can also be drawn from the analysis of contemporary consumer and employee attitudes. Cone Communications/Ebiquity Global CSR research from 2015 [30] reveals that 91\% of global consumers expect companies to be involved in solving social and environmental problems. Thus, the majority of global consumers $(90 \%)$ would boycott the company if they found out about unethical business practices. Global consumers are also able to bear certain costs related to the CSR concept. Most of them (71\%) declare that they would pay more for a socially or environmentally responsible product. $81 \%$ are able to consume less to conserve natural resources. $61 \%$ declare that they prefer to borrow or share goods rather than buy new ones. Moreover, $62 \%$ would prefer to work for a socially responsible company, even if it offered a lower salary than another socially unsuitable company. A total of $57 \%$ would accept a poorer quality product but more socially and environmentally responsible. A total of $61 \%$ of consumers use Social Media to engage in CSR. Additionally, research in Poland [6,13], and Georgia [31-33] has indicated an increase in social awareness of CSR as an important reason for the implementation of the CSR concept. Although research in Georgia [32] shows the perceived shortages by society in terms of access to information on CSR practices in Georgian companies. In Poland, some authors [13] directly refer to the fear of losing good reputation by companies as the reason for implementing CSR, thus referring to the theory of legality and its links with CSR. Additionally, the paper [34] shows that companies implementing CSR are an attractive workplace for employees, especially from the millennials generation. Thus, CSR is perceived as a way to achieve success in the modern world economy, one of the ways to build the company's image and a way to meet customer expectations [6].

The analysis of the historical approach to the development of the CSR concept and the observation of contemporary consumer attitudes, both global, as well as in Poland and Georgia, let us notice a constant increase in society's awareness of the responsibility of companies for their activities, not only in the context of law and economy. Therefore, we present a hypothesis corresponding to the first research question, in which we assume that:

Hypothesis 1 (H1). Changes in awareness and increased consumer expectations, as well as building a positive image of the company thanks to CSR are, in the opinion of students, the most common reasons for the implementation of the CSR concept by companies.

\subsection{Characteristic Activities of Companies Implementing CSR}

CSR research, conducted by scientists [20,35-37], and the historical view on the implementation of the CSR concept show, that we can now distinguish three distinct groups of CSR activities, resulting from the aforementioned historical approach. These are the areas of activity: (1) philanthropic, (2) pro-employee, (3) pro-ecological. Philanthropic activities mainly include: financial support for charity organizations, schools, clubs, associations, amusement and educational parks, fire brigades, IT centres, organizing internships for pupils and students. Pro-employee activities primarily include training for employees as part of encouraging career development and lifelong learning, supporting mothers' work through flexible working hours, promoting equal opportunities for women and people over 45 years, funding awards for academic achievement of employees' children, organiz- 
ing employee trips. Pro-ecological activities include: implementation of environmental management systems, introduction of less energy-consuming technologies, closed production cycle, use of non-toxic, biodegradable products, recycling of local waste, recycling in cooperation with suppliers, use of recycled materials in production, use of ecological cleaning equipment and procedures, use of environmentally friendly materials (chemicals, intelligent coatings that are easy to clean), furnishing the company with heating panels, use of rainwater for washing, sponsoring environmental education programmes for children, partnership in environmental projects in the city and training employees in paying attention to ecological problems.

Some scientists subject these groups of CSR activities to a specific classification and form nomenclature for them. An example of this can be works [38,39], in which CSR activities are classified into: Corporate Operating Performance (COP) and Corporate Social Performance (CSP). COP activities primarily benefit the company's closest stakeholders, such as employees and suppliers. CSP activities are oriented towards further company stakeholders, such as local communities.

In order to organize CSR activities in Poland [20], has developed a CSR maturity model. This model makes it possible to identify incidental, tactical or strategic levels of involvement of Polish companies in CSR. The incidental level consists of activities of companies in the field of CSR defined as ad hoc, unplanned, random or non-existent. The tactical level consists of activities defined as inconsistent implementation of planned, repeated projects and instrumental motivation. The strategic level consists of activities, in which the CSR concept permeates every aspect of the organization and is integrated with the company's business strategy. Research [20] has shown that, in Poland, about half of the companies use CSR at the incidental level, about $30 \%$ at the tactical level and about $20 \%$ at the strategic level. Moreover, small and medium-sized enterprises currently show the lowest CSR maturity, which is in line with the trends prevailing also in the works of other researchers in Poland [13,37] and in the world [40-42]. Moreover, as in other countries, CSR maturity is industry-specific [40,42,43], but most industries in Poland do not have generally accepted CSR standards. The conclusion is that, although Poland has significantly improved its institutional CSR context over the last 20 years, the level of CSR practices in enterprises is still quite low. That is why CSR researchers in the Polish reality also focus on the issues of educating future managers in the field of business ethics, especially the issue of CSR [6]. In turn, Georgia lacks detailed information on what companies do in the field of CSR [32], which suggests the presence of CSR at an incidental level. What is more, research $[44,45]$ indicates that Georgia obtained a low index in such areas as: gender egalitarianism, future orientation and performance orientation, which leads to the conclusion that the poor development of CSR in Georgia is conditioned by the cultural characteristics of the local society [44].

Despite the incidental level of CSR implementation in both Poland and Georgia, it should be emphasized that the undertaken activities in the field of CSR are accompanied by promotion. Publicizing corporate CSR initiatives has gained in importance and, according to [46], communication spending in this area are in third place in the budget positions of large corporations. Public relations tools [47], social media [48,49], websites, company reports, information on philanthropy [50], as well as corporate image and brand positioning strategies [51] are used to communicate CSR activities. Therefore, both environmental issues, as well as human and employee rights, have become a permanent fixture in the social consciousness. Therefore, we present a hypothesis corresponding to the second research question, in which we assume that:

Hypothesis 2 (H2). In the opinion of students, focusing on ethical values in human resource management and on pro-ecological solutions are the most common characteristics of companies that have implemented CSR. 


\subsection{Attitudes Regarding the Impact of CSR on the Profitability of Companies}

CSR is considered a concept that, on the one hand, generates costs for companies, that could be borne by other institutions instead of CSR, and, on the other hand, leads to increased financial results, thanks to the competitive advantage achieved through CSR. Therefore, the question arises whether the revenues generated by CSR activity outweigh its costs. Many researchers have sought answers to this question [21-27]. For example, Hemingway and Maclagan [52] believe that CSR provides space and a cover for fraudulent activities of management, which imposes the negative nature of CSR. Similarly, [28,53,54] are sceptical about the concept of CSR, pointing to the possibility of some kind of manipulative and greenwashing practices under the guise of altruistic concern.

However, although some researchers point to the negative impact of CSR on financial results, due to manipulative practices in the field of CSR, there are also those, who perceive CSR as a source of competitive advantage for companies [55,56]. The main premise confirming the positive impact of CSR on the company's financial results is the stakeholder theory $[25,26]$. According to this theory, lasting relationships with stakeholders generate profit for the company, therefore managing these relationships is the basis for creating value for the company. The research [21] confirmed the validity of Freeman's theory. They consider CSR as a strategy creating legitimacy, reputation, and competitive advantages. The implementation of CSR creates satisfied key stakeholders, who ensure the effectiveness of the company's operations and reduce its costs. For example, satisfied employees provide a company with productive work and reduced employment and training costs. In turn, satisfied customers reward the company with repetitive purchasing decisions, providing it with income. Satisfied investors borrow capital at a lower rate, which lowers the cost of capital. Satisfied with ecological management, the company's community lowers advertising costs, while satisfied regular suppliers lower the costs of certification and quality. Moreover, research $[46,57,58]$ has shown that the implementation of CSR causes the company's customers to identify with it and become branded diplomats. A similar result of the research on the company's reputation was obtained by [59-61]. The results of these studies are also confirmed by the report [30], according to which, if a company implements CSR, it can count on trust ( $90 \%$ of global consumers), loyalty ( $88 \%$ ) and a positive image $(93 \%)$.

Although literature studies indicate that the idea of CSR can be perceived as generating costs that reduce the profits of companies, scientists more and more often provide evidence that the implementation of the CSR concept also generates revenues that not only cover the costs of its implementation, but also allow to achieve a competitive advantage. Therefore, we present a hypothesis corresponding to the third research question, in which we assume that:

Hypothesis 3 (H3). In the opinion of young people, the implementation of CSR principles in companies does not reduce the profitability of these companies.

\subsection{Attitudes towards the Use of Knowledge in the Field of CSR}

Global emphasis on environmental, social and economic issues regulated by law, which is very often mentioned in publications concerning the study of CSR implementation, especially in Poland (cf. $[6,20]$ ) and the perspective that they should be incorporated into the processes functioning in companies, arouse in the society the need to educate its members in this area. The more so because, as mentioned in [14], incompetent CSR activities may be badly received by the society. Moreover, the more and more frequent presentation of the CSR concept as a way to achieve success in the contemporary world economy, building the company's image and meeting customer expectations increases the need for CSR activities, as it indicates a positive impact of CSR implementation on the financial results of companies. On the other hand, such works as $[13,20]$, indicate a lack of strategy in activities related to CSR, which most probably result from the lack of knowledge on the subject. Therefore, we present a hypothesis corresponding to the fourth research question, in which we assume that: 
Hypothesis 4 (H4). Most students agree that knowledge of the ethical aspects of business activities is useful in their professional life.

\section{Materials and Methods}

\subsection{Sample and Data Collection}

The research results were collected in 2019 via an electronic questionnaire. Data from Poland comes from the University of Economics in Katowice, where 482 students (307 women and 175 men) were surveyed. In Georgia, 118 students (61 women and 57 men) completed the questionnaire, from a total of four universities: Ilia Uni, Tbilisi State Uni, Technical University and Black Sea Uni. Due to the demographic differences between Poland and Georgia (the population of Georgia is much smaller than the population of Poland), the disproportion in the number of students from both countries was considered favourable-because it reflects the reality. The distribution of the number of respondents by age and gender is presented in the table below (Table 1 ).

Table 1. Structure of respondents.

\begin{tabular}{ccccc}
\hline Variable & Value & Poland & Georgia & Total \\
\hline \multirow{3}{*}{ Age } & Up to 20 & $59 \%$ & $33 \%$ & $54 \%$ \\
& $21-24$ & $38 \%$ & $55 \%$ & $41 \%$ \\
& Above 25 & $3 \%$ & $12 \%$ & $5 \%$ \\
\hline \multirow{2}{*}{ Gender } & Female & $64 \%$ & $52 \%$ & $61 \%$ \\
& Male & $36 \%$ & $48 \%$ & $39 \%$ \\
\hline
\end{tabular}

\subsection{Measures}

The questions and measuring scales of the questionnaire used for the research are presented in Table 2. Moreover, the questionnaire contained a record with questions about gender and age.

Table 2. The relationship of research questions and questions in the questionnaire.

\begin{tabular}{|c|c|c|}
\hline Research Question & Question & Scaling the Answers \\
\hline \multirow{3}{*}{ RQ1 } & $\begin{array}{c}\text { Select the sentences that, in your opinion, reflect the idea of Corporate Social } \\
\text { Responsibility the best. }\end{array}$ & $\begin{array}{l}\text { Multiple choice } \\
\text { nominal scale }\end{array}$ \\
\hline & $\begin{array}{c}\text { What, according to you, determined the creation and development of the idea of } \\
\text { Corporate Social Responsibility? }\end{array}$ & $\begin{array}{l}\text { Multiple choice } \\
\text { nominal scale }\end{array}$ \\
\hline & $\begin{array}{l}\text { According to you, what are the main reasons for companies to implement the } \\
\text { principles of Corporate Social Responsibility }\end{array}$ & $\begin{array}{l}\text { Multiple choice } \\
\text { nominal scale }\end{array}$ \\
\hline \multirow{2}{*}{ RQ2 } & $\begin{array}{l}\text { What internal (inside a company) activities, according to you, reflect the idea of } \\
\text { Corporate Social Responsibility in everyday business practice? }\end{array}$ & $\begin{array}{l}\text { Multiple choice } \\
\text { nominal scale }\end{array}$ \\
\hline & $\begin{array}{l}\text { What external (outside a company) activities, according to you, reflect the idea } \\
\text { of Corporate Social Responsibility in everyday business practice? }\end{array}$ & $\begin{array}{l}\text { Multiple choice } \\
\text { nominal scale }\end{array}$ \\
\hline RQ3 & $\begin{array}{l}\text { Does the introduction of the principles of Corporate Social Responsibility, in } \\
\text { your opinion, cause lower profitability of the company? }\end{array}$ & 5-point Likert scale \\
\hline \multirow{3}{*}{ RQ4 } & $\begin{array}{c}\text { Do you think that knowledge about ethical aspects of management is useful in } \\
\text { future professional life? }\end{array}$ & 5-point Likert scale \\
\hline & $\begin{array}{l}\text { Do you see the need to constantly develop and enrich knowledge from business } \\
\text { ethics as an important element shaping the attitude of employer and employee? }\end{array}$ & 5-point Likert scale \\
\hline & $\begin{array}{l}\text { Do you think that the students of the University should deepen their knowledge } \\
\text { concerning the ethical aspects of corporate activities? }\end{array}$ & 5-point Likert scale \\
\hline
\end{tabular}




\subsection{Data Analysis}

The obtained answers were subjected to statistical analysis in terms of obtaining answers to the hypotheses and research questions posed. The results were discussed taking into account the nationality and gender of the respondents, looking for hidden relationships. For this purpose, the Pearson chi-square test of independence was performed for the Likert scale questions. In cases, where the expected number obtained was too small, the Fisher exact test was applied. In turn, for questions with a multiple choice nominal scale, differences between the studied populations were searched for using the test for two proportions-separately for each possible answer. The assumed level of significance was $0.05[62,63]$. The results of the analyses are presented in charts, in accordance with the recommendations of Knafik [64,65]. The test results for multiple choice scales are presented in the butterfly chart, also known as the tornado diagram [66]. The results for the single choice scales are presented on the diverging bar chart [67].

\section{Results}

\subsection{Reasons for Implementing the CSR Idea}

In order to verify the $\mathrm{H} 1$ hypothesis, the respondents were asked about the main reasons for implementing CSR principles by the companies. It should be noted that the respondents chose a maximum of three answers. The frequencies of answers for Poland and Georgia were calculated and the significance of the difference between the fractions was calculated. Figure 1 presents the results.

The main reasons for companies to implement the principles of CSR

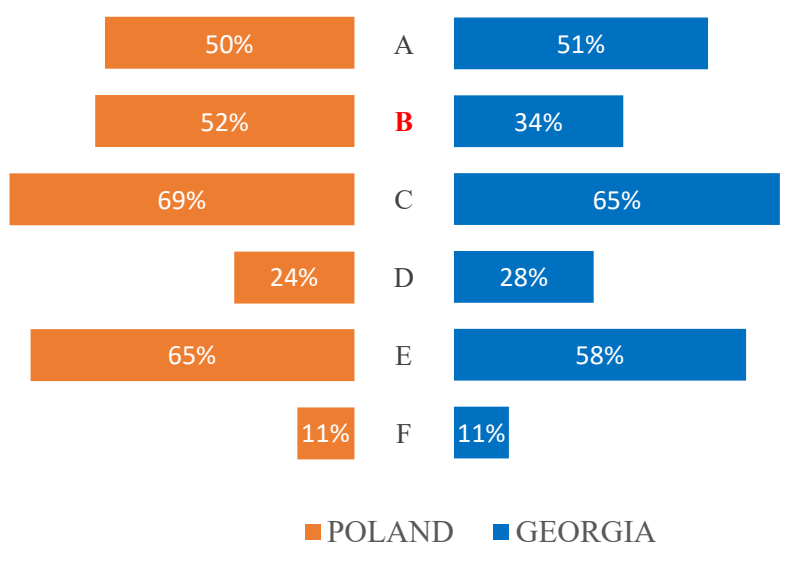

Figure 1. The main reasons for companies to implement the principles of CSR according to students of Poland and Georgia: A-Expectation from customers; B-Developing ethical sensitivity; C-Companies realise that a purely economic approach to business is not enough to be successful in today's world; D—Companies are sensitive to social needs; E-Building the company's image; F-I have no opinion, I don't know. Note: Significant differences for the 0.05 significance level are marked in red.

The most frequently selected answer in Poland and Georgia was the statement that entrepreneurs realise that a purely economic approach in their activities is not enough to achieve success in today's world (69\% and 65\%). The second most frequently chosen answer was building the company's image (65\% and $58 \%$ ). In these respects, the respondents of both countries agreed. However, significantly more students from Poland than from Georgia marked the answer regarding developing ethical sensitivity $(p=0.0005)$. In Poland, no significant differences were found in the answers of men and women. The most common answers were $\mathrm{C}$ and $\mathrm{E}$, although slightly more women chose the answer $\mathrm{E}$ first $(68 \%$ and $63 \%)$, while men most often chose the answer C (72\% and $64 \%)$. In Georgia, as in 
Poland, there were no significant differences as to the substantive answers, but there were significantly more men who avoided answers (F: I have no opinion, I don't know; $18 \%$ and $5 \% ; p=0.0286)$.

Supplementary questions, verifying the $\mathrm{H} 1$ hypothesis, were the question about the reasons for the emergence and development of the CSR idea and the question about the understanding of CSR by the respondents. As before, these were multiple choice questions. The frequency of answers for Poland and Georgia and the significance of the difference between the fractions were calculated. Figure 2 presents the results.

What determined the creation and development of the idea of CSR

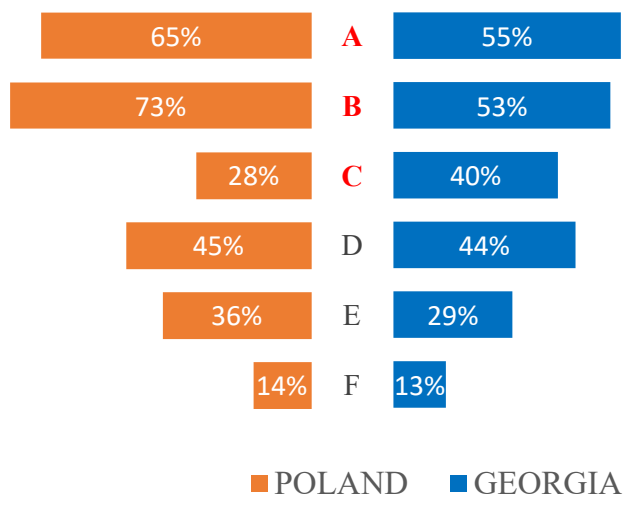

Figure 2. What determined the creation and development of the idea of CSR in opinions of students of Poland and Georgia? A-Increase in social expectations; B-Changes in consumer awareness; C-The need for credibility of the EU economic policy; D-The need to create long-term economic efficiency of enterprises; E-Media operation; F-Don't know. Note: Significant differences for the 0.05 significance level are marked in red.

The most common answer in Poland was the answer B regarding changes in consumer awareness as the reason for the idea of CSR (73\%). Secondly, the respondents indicated answer A, which meant an increase in social expectations (65\%). Additionally, these two responses were selected—equally-in Georgia ( $53 \%$ and $55 \%$ ). Despite a similar tendency, the respondents of both countries marked the answers A $(p=0.0382), \mathrm{B}(p<0.001)$ and C $(p=0.0106)$ with significantly different intensities. Proportionally more Polish students indicated A and B, while answer C (the need for credibility of the EU economic policy) was chosen more often in Georgia ( $40 \%$ and $28 \%$ ). The distribution of answers by nationality and gender (Table 3 ) shows that, in Poland, the most frequent answer of women was $\mathrm{B}$ $(75 \%)$ and A $(61 \%)$, and men-A (72\%) and B $(69 \%)$. Notably more men chose answer A $(p=0.0142)$. However, significantly more women marked E (media activity; $40 \%: 28 \%$; $p=0.0096)$. Georgian students had a slightly more gender-specific answers. The most common answer of women was B (64\%), then A (54\%), while men: A $(56 \%)$, and then B and $D$ equally, pointing to, apart from changes in consumer awareness, also the need to create long-term economic efficiency of enterprises $(40 \%)$. Significantly more women marked the answer B ( $p=0.0104)$, while significantly more men were undecided (F: I don't know; $21 \%$; $p=0.0086)$.

The results of the answers to the question regarding the understanding of CSR by the respondents are illustrated in Figure 3.

In both countries, the most frequent answers were $\mathrm{F}$ and $\mathrm{E}$. The majority of respondents understand CSR as running a business in such a way, as to take into account ethical values, law, respect for employees, society and the natural environment (76\% in Poland and 55\% in Georgia), as well as providing services and products in a way, that does not degrade the natural and social environment (58\% and 53\%). Although the results presented in Figure 1 
show a significant difference between Poland and Georgia for the answer F $(p<0.001)$, it is the dominant answer in both countries. Moreover, the respondents of both countries differed significantly in terms of the frequency of selecting the answers: A $(p=0.0001)$, $\mathrm{C}(p=0.0498), \mathrm{D}(p=0.0004)$ and $\mathrm{G}(p=0.0354)$. In Poland, no major gender differences were noticed in the answers (Table 4$)$. Only that more women marked answer A $(p=0.0486)$, while more men marked G $(p=0.0152)$. However, in Georgia, significant differences, confirmed by the test, concerned the answers: B ( $38 \%$ women and $21 \%$ men; $p=0.0478$ ) and I ( $64 \%$ women and $35 \%$ men; $p=0.0017)$.

Table 3. Significant gender differences: What determined the creation and development of the idea of CSR in opinion of students?

\begin{tabular}{|c|c|c|c|c|c|c|}
\hline \multirow{3}{*}{ Responses } & \multicolumn{3}{|c|}{ Poland } & \multicolumn{3}{|c|}{ Georgia } \\
\hline & \multicolumn{2}{|c|}{ Percentage } & \multirow{2}{*}{$\begin{array}{c}\begin{array}{l}\text { Significance of } \\
\text { the Difference }\end{array} \\
p \text {-Value }\end{array}$} & \multicolumn{2}{|c|}{ Percentage } & \multirow{2}{*}{$\begin{array}{c}\begin{array}{c}\text { Significance of } \\
\text { the Difference }\end{array} \\
p \text {-Value }\end{array}$} \\
\hline & Female & Male & & Female & Male & \\
\hline A: Increase in social expectations & $60.91 \%$ & $72.00 \%$ & 0.0142 & $54.10 \%$ & $56.14 \%$ & 0.8237 \\
\hline B: Changes in consumer awareness & $74.59 \%$ & $69.14 \%$ & 0.1970 & $63.93 \%$ & $40.35 \%$ & 0.0104 \\
\hline E: Media operation & $39.74 \%$ & $28.00 \%$ & 0.0096 & $32.79 \%$ & $24.56 \%$ & 0.3242 \\
\hline F: Don't know & $14.01 \%$ & $14.29 \%$ & 0.9325 & $4.92 \%$ & $21.05 \%$ & 0.0086 \\
\hline
\end{tabular}

Note: Significant differences for the 0.05 significance level are marked in red.

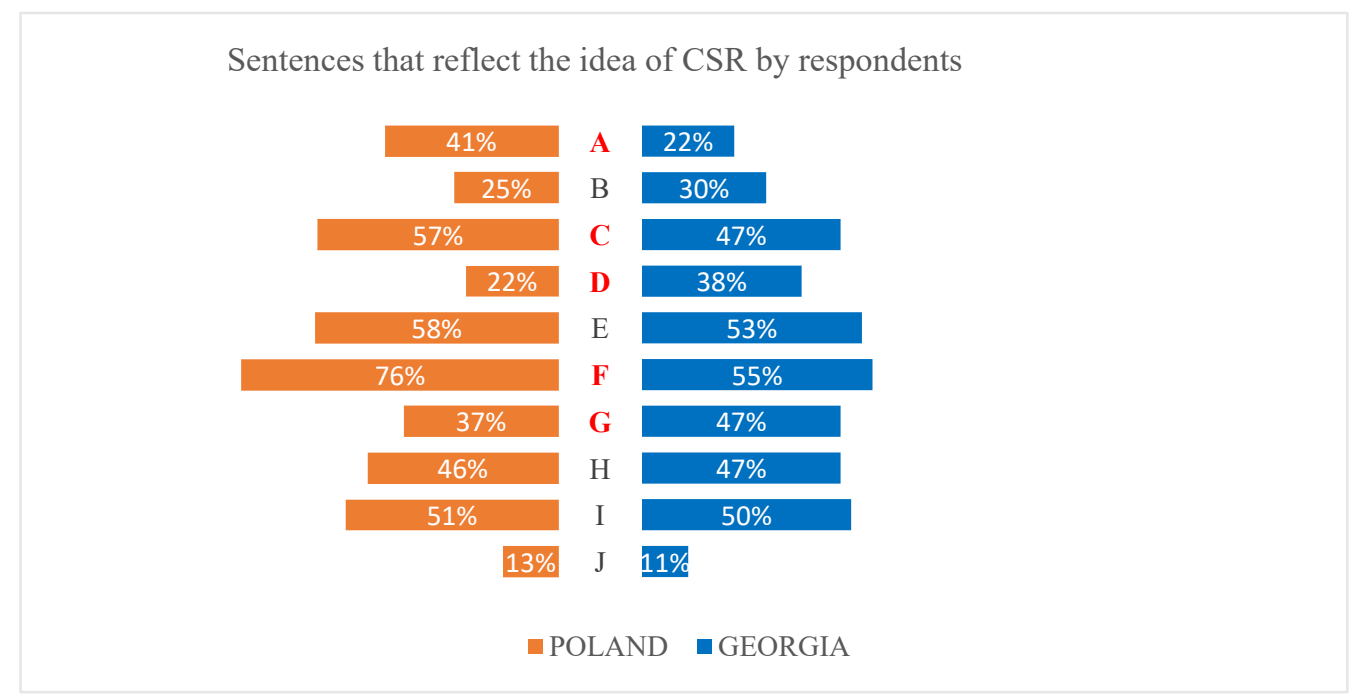

Figure 3. Sentences that reflect the idea of CSR by nationality: A-Achieving sustainable profit, while wisely shaping relations with all stakeholders; B-A management tool that lets you use the process of building a dialogue with stakeholders, in order to improve the company's development strategy; $\mathrm{C}$-The philosophy of running a business based on building lasting, transparent relationships with all interested parties: incl. with employees, customers, suppliers, shareholders, competition and the local community; D-Building a strategy of competitive advantage in the market based on ensuring lasting value for both shareholders and other stakeholders; E-Providing services and products in a way, that does not degrade the natural and social environment; F-Running a business in such a way, as to take into account ethical values, law, respect for employees, society and the natural environment; G-Building and implementing a social commitment strategy that exceeds legal obligations, for the benefit of all citizens, in accordance with socially accepted ethical standards; $\mathrm{H}-$ Contributing to sustainable development by working with employees, as well as local and global communities, to improve the quality of life for all citizens; I-Voluntary consideration of social, ethical and environmental aspects in business activities; J-I have no opinion, I don't know. Note: Significant differences for the 0.05 significance level are marked in red. 
Table 4. Significant gender differences: Sentences that reflect the idea of CSR.

\begin{tabular}{|c|c|c|c|c|c|c|}
\hline \multirow{3}{*}{ Responses } & \multicolumn{3}{|c|}{ Poland } & \multicolumn{3}{|c|}{ Georgia } \\
\hline & \multicolumn{2}{|c|}{ Percentage } & \multirow{2}{*}{$\begin{array}{c}\begin{array}{c}\text { Significance of } \\
\text { the Difference }\end{array} \\
p \text {-Value }\end{array}$} & \multicolumn{2}{|c|}{ Percentage } & \multirow{2}{*}{$\begin{array}{c}\begin{array}{c}\text { Significance of } \\
\text { the Difference }\end{array} \\
p \text {-Value }\end{array}$} \\
\hline & Female & Male & & Female & Male & \\
\hline $\begin{array}{l}\text { A: Achieving sustainable profit, while } \\
\text { wisely shaping relations with } \\
\text { all stakeholders }\end{array}$ & $44.63 \%$ & $35.43 \%$ & 0.0486 & $19.67 \%$ & $24.56 \%$ & 0.5220 \\
\hline $\begin{array}{l}\text { B: A management tool that lets you } \\
\text { use the process of building a dialogue } \\
\text { with stakeholders, in order to improve } \\
\text { the company's development strategy }\end{array}$ & $26.38 \%$ & $21.71 \%$ & 0.2529 & $37.70 \%$ & $21.05 \%$ & 0.0478 \\
\hline $\begin{array}{l}\text { G: Building and implementing a social } \\
\text { commitment strategy that exceeds }\end{array}$ & & & & & & \\
\hline $\begin{array}{l}\text { legal obligations, for the benefit of all } \\
\text { citizens, in accordance with socially } \\
\text { accepted ethical standards }\end{array}$ & $32.90 \%$ & $44.00 \%$ & 0.0152 & $44.26 \%$ & $50.88 \%$ & 0.4721 \\
\hline $\begin{array}{l}\text { I: Voluntary consideration of social, } \\
\text { ethical and environmental aspects in } \\
\text { business activities }\end{array}$ & $49.51 \%$ & $53.14 \%$ & 0.4431 & $63.93 \%$ & $35.09 \%$ & 0.0017 \\
\hline
\end{tabular}

Note: Significant differences for the 0.05 significance level are marked in red.

Summarizing the presented results, it should be stated that the conducted research confirms the correctness of the $\mathrm{H} 1$ hypothesis. The most common reasons for implementing the idea in companies and for the development of CSR concepts in general are related, in the opinion of the respondents, to changes in awareness and increase in consumer expectations. Moreover, the respondents admit that, thanks to the implementation of the CSR concept, companies want to build their positive image.

\subsection{Characteristic Activities of Companies Implementing CSR}

In order to verify the $\mathrm{H} 2$ hypothesis, questions were asked about the internal and external activities characterizing the companies that implemented CSR. The respondents selected a maximum of 3 answers. The results are shown in figures (Figures 4 and 5)

Internal activities in everyday business practice that reflect the idea of CSR

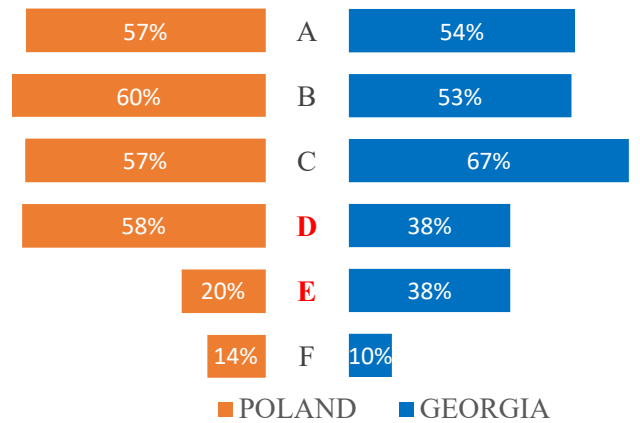

Figure 4. Internal activities in everyday business practice that reflect the idea of CSR, according to students in Poland and Georgia: A-Human Resources management; B-Ethical programmes for employees; C-Occupational Health and Safety; D-Environmental protection management; E-Principles of corporate governance; F-I don't know. Note: Significant differences for the 0.05 significance level are marked in red. 
External activities in everyday business practice that reflect the idea of CSR

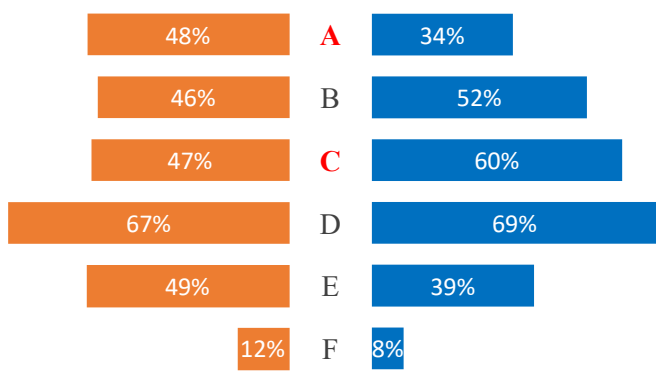

- POLAND MGEORGIA

Figure 5. External activities in everyday business practice that reflect the idea of CSR, according to students in Poland and Georgia: A-Maintaining contact with the local community; B-Good relationships with business partners and suppliers; C-Good relations with customers; D-Respecting human rights in action; E-The use of pro-ecological solutions; F-I don't know. Note: Significant differences for the 0.05 significance level are marked in red.

The most frequently selected answer regarding the company's internal activities, which, in everyday economic practice, are the means of implementation of the CSR idea in Poland, was answer B (60\%), while the next ones (D, A and B) had a very similar frequency (58\% and 57\%). Thus, Polish students equally marked such activities as: ethical programmes for employees, human resources management, occupational health and safety, as well as environmental protection management. Whereas, in Georgia, the most common answer was occupational health and safety (C: 67\%). However, significant differences in the marked responses in both countries showed D and $\mathrm{E}$ (for $p$-value $=0.0002$ and $p<0.001$ ). In terms of daily activities in enterprises, which can be seen in CSR, Polish students marked environmental management (D) much more often than their Georgian colleagues. For the latter, however, CSR was more often associated with the principles of corporate governance (E). There were no significant differences between answers and gender in Poland. However, in Georgia, definitely more women selected answer A (62\%: 44\%; $p=0.0448)$.

Analyzing the differences between the countries, it can be seen that, in Poland, the issue of ecology is treated with more attention than in Georgia, where the issues of occupational health and safety, as well as the principles of corporate governance come to the fore. Therefore, we have here a reference to the company's internal stakeholders and typical employee issues. The perception of CSR in Georgia in this aspect is also present in research [33], in which CSR focused on employee rights ensures a balance between work and private life and improves the health and safety of employees. The differences in terms of ecology may be explained by the observations contained in the research [44], which indicate that the low value of such an indicator as the future orientation, quite strongly related to the issue of ecology, leads to a weaker development of CSR in this area in Georgia, compared to other countries. In turn, the interest in ecological issues in Poland can be explained by research [68], which shows that the activities of Polish companies in the field of environmental protection are one of the most common and are oriented towards eco-education, optimization of resource use and elimination of waste, the use of new technologies and innovative solutions, in order to create new pro-ecological consumption patterns, formally strengthen all undertaken activities in the form of certification.

When asked what activities outside the company, in the everyday work, show the implementation of the CSR idea in both countries, the most common answer was D (67\% and $69 \%$ ). Respondents in both countries considered respect for human rights in action to be the most important aspect of external activities of enterprises. Significant differences were observed in answers A $(p=0.0044)$ and C $(p=0.0129)$. Definitely more Poles indicated 
maintaining contact with the local community (A) as the external activities of companies under CSR, while more Georgians selected the option: good relations with customers (C). There were no significant gender differences in answers in Poland or Georgia.

Summarizing the results of the research, it can be said that, according to the opinions of students both in Poland and Georgia, orientation towards ethical values in the field of human resource management and pro-ecological solutions are the most common characteristics of companies that have implemented CSR. Thus, the obtained results confirm the second hypothesis. However, it is worth adding, when it comes to the verification of the second hypothesis, that the responses to the perception of external activities of companies implementing CSR indicate a great importance of respecting human rights in both analyzed countries. Therefore, this speaks in favour of enriching the original second hypothesis with this issue.

\subsection{Attitudes Regarding the Impact of CSR on the Profitability of Companies}

In order to examine the views of the respondents regarding the impact of CSR on the profitability of companies, they were asked whether the introduction of CSR principles reduces the company's profitability. They were asked to mark one of the five answers (according to the Likert scale). The results for both countries were gathered together in Figure 6. The chi-square test of independence confirmed the existence of dependence of the answers given on the respondents' country $(p<0.001)$.

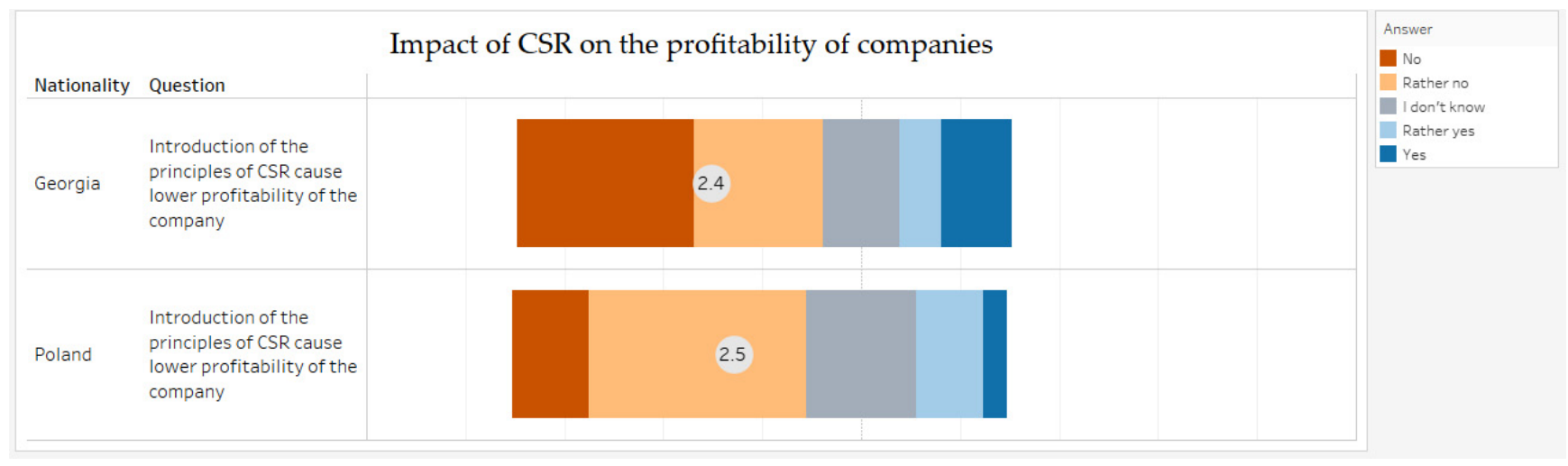

Figure 6. Whether the introduction of the principles of CSR cause lower profitability of the company according to Georgian and Polish students. 1-No; 2-Rather no; 3-I don't know; 4-Rather yes; 5-Yes. In the circle, the average value obtained from the given question is shown.

When analyzing Figure 6, it should be noted that the question presented in it was inverted, i.e., the answers "no" and "rather no" should be treated as positive, while the answers "yes" and "rather yes" as negative. Thus, despite the fact that the respondents from both countries indicated different individual answers, taking into account their attitude: positive to CSR (answers: "no" and "rather no"), together 62\% (Georgia) and 59\% (Poland), and negative (answers: "yes" and "rather yes"), together respectively: $23 \%$ and $19 \%$, their answers showed no significant difference $(p>0.05)$. Most of the respondents do not believe that the introduction of CSR would reduce the company's profitability. In this way, it is possible to confirm the correctness of the third hypothesis, although the authors expected that the results would be more unambiguous in the direction of the answers "no" and "rather no".

The Pearson chi-square test of independence was carried out by examining the dependence of the answers given on the gender of the respondents in individual countries. The test result indicated the existence of this relationship, both among students in Georgia $(p=0.0376)$ and in Poland $(p=0.007443)$. 


\subsection{Attitudes towards the Usefulness of Knowledge in the Field of CSR}

In order to answer the fourth research question, a diverging bar chart was created, presenting the answers to three questions of the questionnaire (Figure 7).

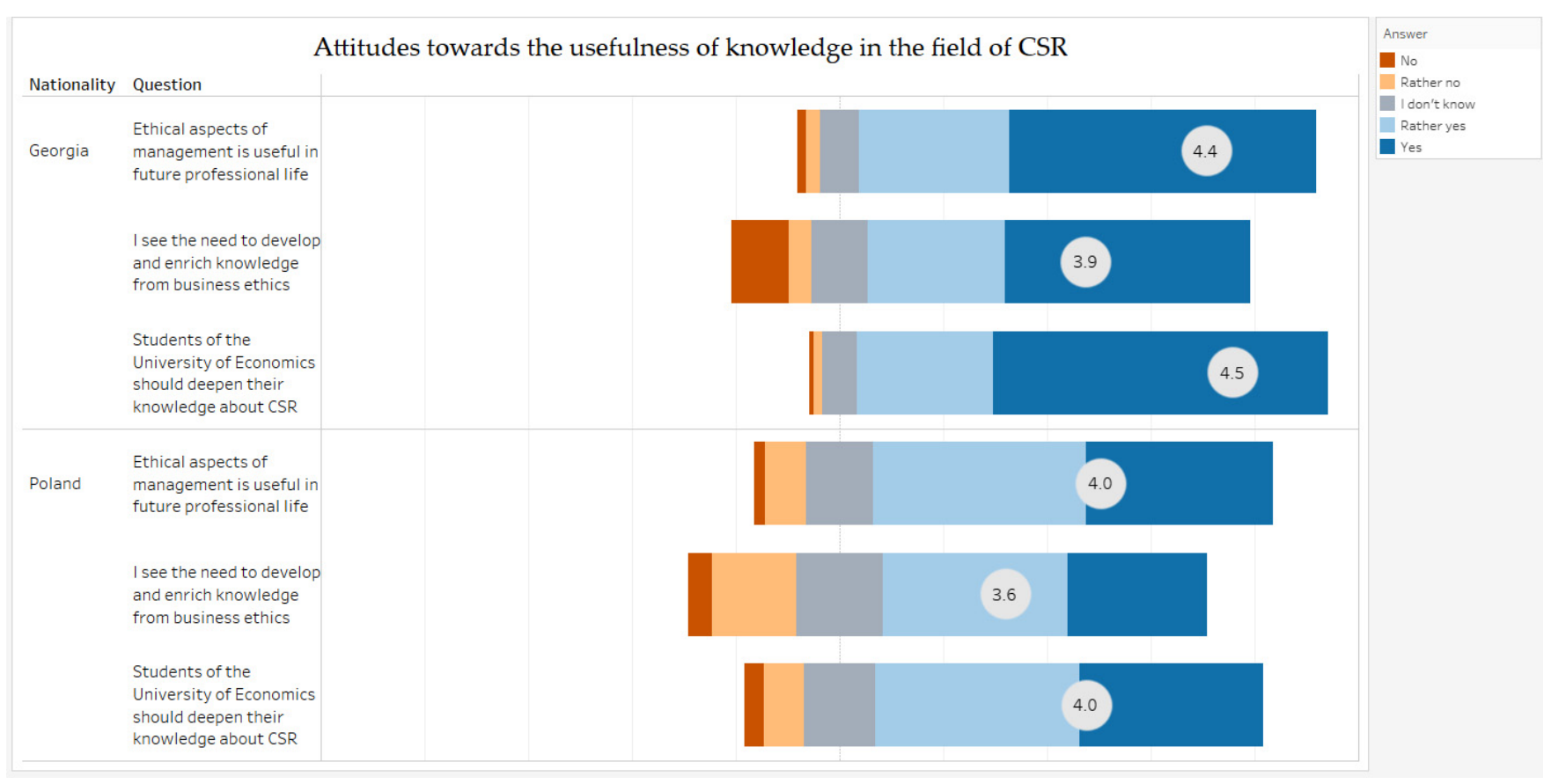

Figure 7. Attitudes towards the usefulness of knowledge in the field of CSR. 1-No; 2-Rather no; 3-I don't know; 4-Rather yes; 5-Yes. In the circle, the average value obtained from the given question is shown.

The first of them was aimed at examining the awareness of whether the knowledge about ethical aspects of management is useful in later professional life. The chi-square test of independence showed significant differences in the answers in both countries $(p=0.0001588)$. The vast majority of students confirmed the awareness of the usefulness of this knowledge in their later professional life. There were significantly more such answers in Georgia ( $88 \%$ ), but also in Poland they were the majority (77\%). In turn, by examining the dependence of the answers given on the gender of respondents in individual countries, its existence was confirmed among students in Georgia $(p=0.03505)$. Definitely more women gave an affirmative answer (96\%), while among the undecided there were more men (14\%). Additionally, among students in Poland, the existence of a dependence between the answer and gender was confirmed $(p=0.007798)$. Additionally, more women (albeit with a much smaller share than in Georgia) answered affirmatively (82\%), while the answers "rather no" and "I don't know" were mostly given by men.

The second question concerned the need to constantly develop and enrich knowledge of economic ethics as an important element shaping the attitude of the employer and employee. Additionally here, the vast majority of respondents felt the need to enrich their knowledge of economic ethics as an important aspect shaping the attitudes of employers and employees. As many as 74\% of Georgians answered "yes" or "rather yes", while $63 \%$ of Poles chose the same answers. The chi-square test showed a relationship between the answers and nationality $(p<0.001)$. In Georgia, this relationship is also significant in terms of gender $(p<0.001)$, while in Poland it was not detected $(p=0.5364)$.

The third question concerned the opinion on the obligation to deepen knowledge about the ethical aspects of companies' activities. The independence test confirmed the existence of a dependence between the answers given and nationality $(p<0.001)$. Significantly more Georgians were in favour of the need to deepen their knowledge about the ethical aspects of business activities at universities (91\%), however, the majority of Polish students also 
noticed this need (75\%). Still, there was no relationship between the answers and gender in both countries (Georgia: $p=0.06449$, Poland: $p=0.05395$ ).

\section{Discussion of Findings}

Our research has confirmed the first hypothesis assuming that ethical values, changes in consumer awareness, and the willingness of companies to gain a competitive advantage thanks to CSR are the most common reasons for the implementation of the CSR concept by companies. The differences between the answers of students from both countries related to several issues. The first is the opinion on the developing ethical sensitivity, which was indicated by Polish students significantly more often than in Georgia. In turn, the issue of the need for credibility of the EU economic policy was more important for Georgian students than for Polish students. Moreover, in Poland, men more often attached importance to the issue of increasing social expectations, while women to the role of the media in developing the idea of CSR. In the case of Georgia, men more often than women indicated the issue of changing consumer awareness. Comparing the obtained results with the research [30], a certain convergence can be seen. The dominant number of answers indicating that CSR is perceived as running a business in such a way, as to take into account ethical values, law, respect for employees, society, and the natural environment, both in Poland and Georgia, shows that CSR and the ethical values it entails are perceived as a way to solve social and environmental problems. Students in both surveyed countries present a similar perception of CSR as the global consumers indicated in the research [30]. In turn, the high number of answers related to ecological issues is consistent with the research obtained by [18] and shows that, in both countries, students perceive the issues of providing products and services in a way, that does not degrade the natural environment as very important. The high percentage of answers regarding building lasting relationships with all stakeholders of the company proves the convergence of the results with the research [21], showing the importance of the stakeholder theory for the issue of generating profit for enterprises. An interesting aspect of additional research would be to answer whether students' responses from countries at a different economic level coincide with the presented ones. Therefore, we are considering the possibility of conducting similar research in countries at a lower and higher level of development.

Our research has also confirmed the second hypothesis claiming that orientation towards ethical values in the field of human resource management and pro-ecological solutions are the most common characteristics of companies that have implemented CSR in the analyzed countries. In the analysis of differences between countries, the difference in terms of the greater importance of maintaining contacts with the local community in the perception of Polish students is noticeable, and in the case of Georgian students-greater importance of relations with customers. From these differences, it can be concluded that, for students from Georgia, relations with close stakeholders of companies are more important, while for Polish students-relations with further ones. The approach of Polish students can be explained by the research described in the paper [13], in which employees of Polish branches of international corporations have a similar attitude as students. Therefore, it points to the value system currently functioning in Polish society. By planning further research in this area, we can indicate that retrospective studies could also provide worthy of note results whether CSR's perception is changing in both countries. For example, will the results from both countries be more similar in 5-10 years? In our opinion, this should as well be the direction of future research.

We have also confirmed our third hypothesis assuming a positive attitude of students as regards the impact of CSR on the company's profitability. The results of the research in both countries are consistent with the conclusions about the positive impact of CSR on the profitability of the work of companies of such researchers as [21,26,57], However, a puzzling factor is the large percentage of people in Poland, who are unable to determine the impact of CSR on profitability, which may be related to the research results presented in the paper [20], which emphasize the incidental nature of CSR activities of Polish companies. 
Therefore, the lack of an unequivocal answer by $1 / 5$ of the surveyed Polish students may indicate the awakening of awareness in this regard and the need to change the existing situation. This hypothesis, in turn, can be confirmed by similar studies carried out in a few years. Research at regular intervals could identify a trend in the development of consciousness.

Eventually, our research has also confirmed the fourth hypothesis assuming that in the opinion of students in both countries, knowledge of the ethical aspects of companies' activities is useful in professional life. The explanation of the need to enrich the knowledge and skills in the field of CSR, declared by Polish and Georgian students, can be based on research [13,14], which shows how difficult it is to build a civic community and how much knowledge is needed, so that CSR activities are not perceived as a smokescreen, greenwashing, or simply as incompetent, but in good faith [14]. Considering the results, the question arises what results would be obtained from the research on the introduction by academic teachers of economic courses of CSR content to their subjects. Is the perception of this need by academic teachers similar to the perception of students in both countries? What is the answer to the growing interest on the part of students in these issues? Should it be the adaptation of study programs, or what should be done in this matter?

\section{Implication for Research and Practice}

So far, research in the field of CSR has covered developed or developing countries. Comparative studies between the countries that are between this continuum were in the minority and usually involved closely neighboring countries. Thus, by researching countries such as Poland and Georgia, we filled the identified research gap. Our research has shown that countries slower-moving towards a market economy may have a slightly different perception of the concept of CSR. The concept of CSR can be perceived as activities directed towards closer than further stakeholders of enterprises.

Our research shows that students' awareness of CSR results from all the socially and environmentally responsible activities of companies on the market. Therefore, in the case of a megatrend related to the climate crisis and the need to adapt business to this crisis, it may happen that actions without a clear focus on ecology will be assessed as unsatisfactory. Therefore, companies should take various actions on a voluntary basis. They may concern, for example, the replacement of plastic packaging with more ecological ones, the implementation of the postulates of the zero waste concept or the circular economy.

The obtained results indicate that, although the concept of CSR is known and accepted by the societies of both countries, the complexity of issues related to its implementation in companies suggests the need to increase educational activities and educate personnel in skilfully implementing CSR principles in enterprises. It will be possible, inter alia, thanks to the expansion of the educational offer in this field at economic universities. The need to learn more about the ethical aspects of running a business reported by students in our research indicates that academic curricula should perhaps be directed to the more practical aspects of CSR. The implementation of project forms of teaching can bring satisfactory results, especially in combination with providing students with access to real problems faced by companies that want to be socially responsible. Such forms of teaching might be very well perceived by students.

\section{Limitation}

Although our research has shown that countries slower-moving towards a market economy may have a slightly different perception of the concept of CSR, we realize that comparative studies conducted in only two countries are insufficient to make such conclusions. Thus, we do not generalize our findings but we consider them only as a hypothesis that needs to be verified. Bearing in mind the exploratory nature of our research, we used a simple form of a questionnaire. Investigating with a more sophisticated form of the questionnaire would allow finding a broader context for the issues we are researching. 


\section{Conclusions}

The article poses four research questions and verifies four hypotheses. The research was conducted in the context of differences related to nationality and gender. First of all, we were looking for an answer to the question of what the students' awareness is of the contemporary reasons for implementing the idea of CSR by companies. The conducted research allowed for the positive verification of the first hypothesis and, therefore, both in Poland and in Georgia, ethical values, changes in consumer awareness and the willingness of companies to gain a competitive advantage thanks to CSR are the most common reasons for the implementation of the CSR concept by companies. Secondly, we were looking for an answer to the question about the characteristic activities of companies in the field of CSR. The obtained results, especially those in terms of the perception of internal activities of companies implementing CSR, confirm the second hypothesis. Therefore, both in Poland and in Georgia, orientation towards ethical values in the field of human resource management and pro-ecological solutions are the most common characteristics of companies that have implemented CSR. However, it is worth adding, when it comes to the verification of the second hypothesis, that the responses to the perception of external activities of companies implementing CSR indicate a great importance of respecting human rights in both analyzed countries. Therefore, the verified second hypothesis should also be supplemented with this issue. In Poland, the issue of ecology and relations with the local community (and, therefore, further stakeholders of companies) is treated with more attention than in Georgia, where relations with the closest stakeholders of companies, i.e., employees and customers, come to the fore. Therefore, referring to the history of the development of the CSR concept, it can be seen that Georgia is at a slightly earlier stage of implementing this concept. Thirdly, we looked for an answer to the question of whether, in the opinion of the respondents, the implementation of CSR principles affects the profitability of companies. The obtained results indicate that it is possible to confirm the correctness of the third hypothesis, although the authors expected that the results would more clearly indicate the positive attitude of students as regards the impact of CSR on the company's profitability. The large percentage of the answers "I don't know" in Poland shows, according to the authors, the awareness of young people of the incidental nature of CSR activities, which suggests the need for intensified actions, not only to awaken public awareness, but to educate personnel, who can professionally implement CSR principles in the activities of companies. This conclusion is also confirmed by the results of research related to the last research question, i.e., related to the attitude that students present towards the exploration and usefulness of knowledge about the ethical aspects of business. The fourth hypothesis was confirmed and, therefore, according to the students, knowledge of the ethical aspects of companies' activities is useful in professional life.

Author Contributions: Conceptualization, G.P., I.Z. and A.M.; methodology, I.Z. and A.M.; formal analysis, I.Z. and A.M.; investigation, G.P.; writing-original draft preparation, I.Z. and A.M.; visualization, I.Z. and A.M. All authors have read and agreed to the published version of the manuscript.

Funding: This paper was published as part of statutory research at the Silesian University of Technology, Department of Organization and Management: 13/010/BK_21/0057.

Institutional Review Board Statement: Not applicable.

Informed Consent Statement: Not applicable.

Acknowledgments: We would like to thank Salome Svanaga and Joanna Paliszkiewicz PhD Eng., thanks to whom it was possible to conduct research in Georgia.

Conflicts of Interest: The authors declare no conflict of interest. 


\section{References}

1. GII 2020 Global Innovation Index. Available online: https://www.globalinnovationindex.org/Home (accessed on 29 April 2021).

2. Sołtysik-Piorunkiewicz, A.; Zdonek, I. How Society 5.0 and Industry 4.0 Ideas Shape the Open Data Performance Expectancy. Sustainability 2021, 13, 917. [CrossRef]

3. Zdonek, D.; Król, K. The Impact of Sex and Personality Traits on Social Media Use during the COVID-19 Pandemic in Poland. Sustainability 2021, 13, 4793. [CrossRef]

4. Hysa, B.; Karasek, A.; Zdonek, I. Social Media Usage by Different Generations as a Tool for Sustainable Tourism Marketing in Society 5.0 Idea. Sustainability 2021, 13, 1018. [CrossRef]

5. European Commision 2001 Greenpaper. Available online: https:/ /ec.europa.eu/transparency/regdoc/rep/1/2001/EN/1-2001366-EN-1-0.Pdf (accessed on 29 April 2021).

6. Polok, G. Rola Wyższej Szkoły Ekonomicznej w Propagowaniu Wiedzy o Społecznej Odpowiedzialności Biznesu w: Społeczna Odpo-Wiedzialność-Aspekty Teoretyczne i Praktyczne; Wyd. Uniwersytetu Ekonomicznego w Katowicach. 2011, 64, $185-205$.

7. Roszkowska-Menkes, M.T. Integrating strategic CSR and open innovation. Towards a conceptual framework. Soc. Responsib. 2018, 14, 950-966. [CrossRef]

8. Mirvis, P.; Herrera, M.E.B.; Googins, B.; Albareda, L. Corporate social innovation: How firms learn to innovate for the greater good. J. Bus. Res. 2016, 69, 5014-5021. [CrossRef]

9. Osburg, T. Social Innovation to Drive Corporate Sustainability. In Social Innovation; Springer Science and Business Media LLC: Berlin, Germany, 2013; pp. 13-22.

10. Habek, P. Development of Corporate Social Responsibility in Visegrad Group Countries. Sci. Pap. Silesian Univ. Technol. Organ. Manag. Ser. 2019, 2019, 71-82. [CrossRef]

11. Hąbek, P.; Sujova, E.; Cierna, H. Technology Comparative analysis of CSR reporting practices in Poland and Slovakia. Sci. Pap. Silesian Univ. Technol. Organ. Manag. Ser. 2018, 2018, 51-65. [CrossRef]

12. Global Finance Magazine the World's Richest and Poorest Countries. Available online: https://www.gfmag.com/global-data/ec onomic-data/worlds-richest-and-poorest-countries (accessed on 29 April 2021).

13. Dancewicz, B.; Struve, F. The Influence of MNEs on CSR in Poland. In Corporate Social Responsibility in Poland CSR Sustainability Ethics $\mathcal{E}$ Governance; Długopolska-Mikonowicz, A., Przytuła, S., Stehr, C., Eds.; Springer International Publishing: Cham, UK, 2019; pp. 149-165, ISBN 978-3-030-00439-2.

14. Szumniak-Samolej, J. Social Media for Corporate Social Responsibility Strategy Creation and Communication in Poland. In Corporate Social Responsibility in Poland CSR Sustainability Ethics $\mathcal{E}$ Governance; Długopolska-Mikonowicz, A., Przytuła, S., Stehr, C., Eds.; Springer International Publishing: Cham, UK, 2019; pp. 273-286. ISBN 978-3-030-00439-2.

15. Gallup Inc. 2016 Global Engagement Report. Available online: http://www.shqiperiajone.org/sites/default/files/pdf/2016\%20 Global\%20Civic\%20Engagement\%20Report.pdf (accessed on 29 April 2021).

16. Agudelo, M.A.L.; Johannsdottir, L.; Davídsdóttir, B. A literature review of the history and evolution of corporate social responsibility. Int. J. Corp. Soc. Responsib. 2019, 4, 1. [CrossRef]

17. Chaffee, E.C. 2017 The Origins of Corporate Social Responsibility. Available online: https://heinonline.org/HOL/LandingPage ?handle=hein.journals / ucinlr85\&div=18\&id=\&page= (accessed on 29 April 2021).

18. Carroll, A.B. A history of corporate social responsibility: Concepts and practices. In The Oxford Handbook of Corporate Social Responsibility; Andrew, C.M., Matten, D.J., Moon, D.S., Eds.; Oxford University Press: New York, NY, USA, 2008 ; pp. $19-46$.

19. Harrison, B. Philanthropy and the Victorians. Vic. Stud. 1966, 9, 353-374.

20. Witek-Crabb, A. CSR Maturity in Polish Listed Companies: A Qualitative Diagnosis Based on a Progression Model. Sustainability 2019, 11, 1736. [CrossRef]

21. Maqbool, S.; Zameer, M.N. Corporate social responsibility and financial performance: An empirical analysis of Indian banks. Futur. Bus. J. 2018, 4, 84-93. [CrossRef]

22. Wang, Z.; Sarkis, J. Corporate social responsibility governance, outcomes, and financial performance. J. Clean. Prod. 2017, 162, 1607-1616. [CrossRef]

23. Sánchez-Torné, I.; Morán-Álvarez, J.C.; Perez-Lopez, J.A. The importance of corporate social responsibility in achieving high corporate reputation. Corp. Soc. Responsib. Environ. Manag. 2020, 27, 2692-2700. [CrossRef]

24. Margolis, J.D.; Elfenbein, H.A.; Walsh, J.P. Does It Pay to Be Good. And Does It Matter? A Meta-Analysis of the Relationship between Corporate Social and Financial Performance. SSRN Electron. J. 2009. [CrossRef]

25. Freeman, R.E. Strategic Management: A Stakeholder Approach; Pitman Publishing: Boston, MA, USA, 1984.

26. Freeman, R.E.; Dmytriyev, S. Corporate Social Responsibility and Stakeholder Theory: Learning From Each Other. Symphonya. Emerg. Issues Manag. 2017, 7-15. [CrossRef]

27. Hammann, E.-M.; Habisch, A.; Pechlaner, H. Values that create value: Socially responsible business practices in SMEs-empirical evidence from German companies. Bus. Ethic Eur. Rev. 2009, 18, 37-51. [CrossRef]

28. Moon, J. The Social Responsibility of Business and New Governance. Gov. Oppos. 2002, 37, 385-408. [CrossRef]

29. Du Pisani, J.A. Sustainable development-historical roots of the concept. Environ. Sci. 2006, 3, 83-96. [CrossRef]

30. Cone 2015 Global CSR Study. Available online: https:/ / www.conecomm.com/research-blog/2015-cone-communications-ebiqui ty-global-csr-study (accessed on 29 April 2021).

31. Gigauri, I. Impact of Corporate Social Responsibility on Consumer Purchase Decision. J. Educ. Soc. Res. 2012, 2, 106-111. 
32. Gigauri, I. Communication Needs for Corporate Social Responsibility in Developing Countries: The Case of Georgia. World J. Soc. Sci. 2015, 5, 127-141.

33. Gigauri, I. Corporate Social Responsibility and COVID-19 Pandemic Crisis. Int. J. Sustain. Entrep. Corp. Soc. Responsib. 2021, 6, 30-47. [CrossRef]

34. Klimkiewicz, K.; Oltra, V. Does CSR Enhance Employer Attractiveness? The Role of Millennial Job Seekers' Attitudes. Corp. Soc. Responsib. Environ. Manag. 2017, 24, 449-463. [CrossRef]

35. Dyczkowskaa, J.; Krasodomskab, J.; Michalakc, J. CSR in Poland: Institutional Context, Legal Framework and Voluntary Initiatives. Account. Manag. Inf. Syst. 2016, 15, 206.

36. Wolczek, P. Development of the CSR Concept in Poland-Progress or Stagnation? Soc. Responsib. Organ. Chang. Their Dir. Res. Pap. Wroc. Univ. Econ. 2015, 387, 200-214. [CrossRef]

37. Wołczek, P. Strategic CSR in Poland. In Corporate Social Responsibility in Poland CS, Sustainability Ethics E Governance; Długopolska-Mikonowicz, A., Przytuła, S., Stehr, C., Eds.; Springer International Publishing: Cham, UK, 2019; pp. 289-309, ISBN 978-3-030-00439-2.

38. Harrison, K.; Huang, L. Not all corporate social responsibility (CSR) is created equal: A study of consumer perceptions of CSR on firms post fraud. J. Mark. Theory Pr. 2020, 1-18. [CrossRef]

39. Huang, L. Quality or Responsibility? The Impact of Two Categories of Corporate Social Responsibility on the Consumer-Brand Relationship. Mark. Manag. J. 2015, 25, 27-41.

40. Deegan, C.; Gordon, B. A Study of the Environmental Disclosure Practices of Australian Corporations. Account. Bus. Res. 1996, 26, 187-199. [CrossRef]

41. Ali, W.; Frynas, J.G.; Mahmood, Z. Determinants of Corporate Social Responsibility (CSR) Disclosure in Developed and Developing Countries: A Literature Review. Corp. Soc. Responsib. Environ. Manag. 2017, 24, 273-294. [CrossRef]

42. Holder-Webb, L.; Cohen, J.R.; Nath, L.; Wood, D. The Supply of Corporate Social Responsibility Disclosures Among U.S. Firms. J. Bus. Ethic 2008, 84, 497-527. [CrossRef]

43. Cowen, S.S.; Carolina, N. The Impact of Corporate Characteristics on Social Responsibility Disclosure: A Typology and FrequencyBased Analysis. Account. Organ. Soc. 1987, 12, 111-122. [CrossRef]

44. Shekriladze, M.; Stehr, C. Corporate Social Responsibility in Rising Economies: Georgia. Glob. Chall. CSR Sustain. Dev. 2020, 141-161. [CrossRef]

45. House, R.J.; Hanges, P.J.; Javidan, M.; Dorfman, P.W.; Gupta, V. Culture, Leadership, and Organizations. In The Globe Study of 62 Societies; Sage Publications: New York, NY, USA, 2004; ISBN 1-4522-0812-3.

46. Parguel, B.; Benoît-Moreau, F.; Larceneux, F. How Sustainability Ratings Might Deter 'Greenwashing': A Closer Look at Ethical Corporate Communication. J. Bus. Ethic. 2011, 102, 15-28. [CrossRef]

47. Grunig, L.A.; Grunig, J.E.; Vercic, D. Are the IABC's excellence principles generic? Comparing Slovenia and the United States, the United Kingdom and Canada. J. Commun. Manag. 1998, 2, 335-356. [CrossRef]

48. Castronovo, C.; Huang, L. Social Media in an Alternative Marketing Communication Model. J. Mark. Dev. Compet. 2012, 6, 117-134.

49. Huang, L.; Clarke, A.; Heldsinger, N.; Tian, W. The communication role of social media in social marketing: A study of the community sustainability knowledge dissemination on LinkedIn and Twitter. J. Mark. Anal. 2019, 7, 64-75. [CrossRef]

50. Ziek, P. Making sense of CSR communication. Corp. Soc. Responsib. Environ. Manag. 2009, 16, 137-145. [CrossRef]

51. Du, S.; Bhattacharya, C.; Sen, S. Reaping relational rewards from corporate social responsibility: The role of competitive positioning. Int. J. Res. Mark. 2007, 24, 224-241. [CrossRef]

52. Hemingway, C.A.; Maclagan, P.W. Managers' Personal Values as Drivers of Corporate Social Responsibility. J. Bus. Ethic 2004, 50, 33-44. [CrossRef]

53. Janney, J.J.; Gove, S. Reputation and Corporate Social Responsibility Aberrations, Trends, and Hypocrisy: Reactions to Firm Choices in the Stock Option Backdating Scandal. J. Manag. Stud. 2011, 48, 1562-1585. [CrossRef]

54. Jeon, H.J.; Gleiberman, A. Examining the Role of Sustainability and Green Strategies in Channels: Evidence from the Franchise Industry. J. Mark. Theory Pr. 2017, 25, 189-199. [CrossRef]

55. Falkenberg, J.; Brunsael, P. Corporate Social Responsibility: A Strategic Advantage or a Strategic Necessity? J. Bus. Ethic 2011, 99, 9-16. [CrossRef]

56. McWilliams, A.; Siegel, D.S. Creating and Capturing Value. J. Manag. 2010, 37, 1480-1495. [CrossRef]

57. Sen, S.; Bhattacharya, C. Does Doing Good Always Lead to Doing Better? Consumer Reactions to Corporate Social Responsibility. J. Mark. Res. 2001, 38, 225-243. [CrossRef]

58. Maignan, I.; Ferrell, O.C. Corporate Social Responsibility and Marketing: An Integrative Framework. J. Acad. Mark. Sci. 2004, 32, 3-19. [CrossRef]

59. Sagar, P.; Singla, A. Trust and corporate social responsibility: Lessons from India. J. Commun. Manag. 2004, 8, 282-290. [CrossRef]

60. Fukukawa, K.; Balmer, J.M.T.; Gray, E.R. Mapping the Interface Between Corporate Identity, Ethics and Corporate Social Responsibility. J. Bus. Ethic 2007, 76, 1-5. [CrossRef]

61. Hur, W.-M.; Kim, H.; Woo, J. How CSR Leads to Corporate Brand Equity: Mediating Mechanisms of Corporate Brand Credibility and Reputation. J. Bus. Ethic 2014, 125, 75-86. [CrossRef] 
62. Hogg, R.V.; McKean, J.W.; Craig, A.T. Introduction to Mathematical Statistics, 8th ed.; Pearson: Boston, MA, USA, 2019; ISBN 978-0-13-468699-8.

63. Peck, R. Introduction to Statistics and Data Analysis, 6th ed.; Cengage Learning: Boston, MA, USA, 2018; ISBN 978-1-337-79361-2.

64. Knaflic, C.N. Storytelling with Data: A Data Visualization Guide for Business Professionals; John Wiley \& Sons: Hoboken, NJ, USA, 2015; ISBN 1-119-00225-7.

65. Tufte, E.R. The Visual Display of Quantitative Information. J. Heal. Qual. 1985, 7, 15. [CrossRef]

66. Kaley, A. 2020 Building Butterfly/Tornado Charts-Storytelling with Data (Part II). Available online: https:/ / medium.datadrive ninvestor.com/building-butterfly-tornado-charts-storytelling-with-data-part-ii-ba443648b40e (accessed on 29 April 2021).

67. Weitz, D. 2020 Diverging Bars, Why \& How. Storytelling with Divergences. Available online: https://towardsdatascience.com/d iverging-bars-why-how-3e3ecc066dce (accessed on 29 April 2021).

68. Hys, K. The Practice of CSR in Poland in the Realm of Environment Action. In Proceedings of the 17th International Multidisciplinary Scientific GeoConference (SGEM2017), Albena, Bulgaria, 29 June-5 July 2017; pp. 1035-1041. [CrossRef] 